\title{
The Effects of Service Qualities on Customer Satisfaction, Trust, and Behavioral Intention in Smartphone Shopping Malls
}

\section{스마트폰 쇼핑몰의 서비스품질이 고객만족, 신뢰, 행동의도에 미치는 영향*}

\author{
Seung-Kwon Yang(양승권) $)^{* *}$, Jae-Hyun Shim(심재현) ${ }^{* * *}$
}

Received: October 19, 2018. Revised: November 15, 2018. Accepted: December 05, 2018.

\section{Abstract}

Purpose - Smartphone shopping malls provide customers with a variety of tangible and intangible services including web sites, web design, use convenience, information for products and shopping and various after services. Accordingly, it is needed to expand and classify service qualities based on the various services provided by smartphone shopping malls, and then analyze path structures of smartphone shopping malls' qualities $\rightarrow$ customer satisfaction $\rightarrow$ behavioral intention. The purpose of this study is to categorize the qualities of smartphone shopping mall users based on the e-SERVQUAL by Lee(2002) and the SERVQUAL by Parasuraman et al.(1988, 2005), the smartphone shopping malls' service qualities based on service quality of smartphone shopping malls used in the previous use studies, and the Website quality factors of service industry and to analyze path structure of smartphone shopping mall's qualities $\rightarrow$ customer satisfaction $\rightarrow$ behavioral intention on college students in order to confirm the system of smartphone shopping malls' qualities.

Research design, data, and methodology - This study's survey was carried out on the college students of university located in northeastern of Seoul. It was from December $7-15,2017$, and a total of 240 questionnaires were distributed, with 228 collected. Of them, effective questionnaires used in the final study were a total of 201 except 27 that couldn't be used. In this study, empirical analysis was done with factor analysis, correlation analysis, multiple regression analysis, simple multiple regression analysis and moderating regression analysis by using Statistics Package SPSS18.0.

Results - The study results are as follows: First, smartphone shopping malls' qualities were classified into six categories like customer system quality, Web design quality, convenience quality, information-offering quality, service quality, and product quality. Second, it showed that system quality, Web design quality, and information-offering quality had a positive impact on customer satisfaction, respectively. Third, it suggested that quality factors of smartphone shopping mall users had a positive impact on customer satisfaction in the order of quality, information-offering quality, system quality and Web design quality. Finally, it showed that customer service quality, product quality, and convenience quality did not have a positive impact on customer satisfaction. In addition, it said that customer satisfaction of smartphone shopping mall users had a positive impact on behavioral intention and thereby, the higher the customer satisfaction was, the higher the relations between reuse intention and recommendation intention were. Meanwhile, moderating regression analysis showed that trust did not have moderating effect in the relations between customer satisfaction and behavioral intention. The above study revealed that smartphone shopping malls' qualities were classified into six categories and it was possible to generalize after empirical analysis was made in the path structure.

Conclusions - Smartphone shopping mall users consider usefulness of obtaining shopping information and quality on quick and abundant shopping information more important than access environment of smartphone shopping malls and kind services of smartphone shopping mall managers. Thereby, smartphone shopping mall marketers need to take service qualities like system quality and information-offering quality into more consideration.

Keywords: Smartphone Shopping Mall, Service Quality, Customer Satisfaction, Trust, Behavioral Intention.

JEL Classifications: C12, D12, M11, M31.

\footnotetext{
* The present research has been conducted by the Research Grant of Seoil University in 2018.

** First author, Professor, Dept. of Tax \& Accounting, Seoil
}

University, Korea. E-mail: sk-y1@hanmail.net

*** Corresponding author, Associate Professor, Dept. of Economics, Kyonggi University, Korea.

Tel: +82-2-7685-9419. E-mail: paciko@empal.com 


\section{1. 서론}

유통시장에서 온.오프라인의 경계가 점차 사라지고 있는 가 운데 국내 온라인 쇼핑(인터넷 쇼핑, 모바일 쇼핑 등)은 2015 년 기준 판매매체별 및 상품군별 거래액에서 53.9조 원, 전년 대비 18.8\% 성장한 것으로 나타나고 있다(2017 White Paper on Distribution Industry, Korea Chamber of Commerce and Industry). 이 거래액 중에서 모바일 쇼핑의 거래액은 의류·패 션 및 관련 상품, 스포츠·레저용품, 화장품, 아동·유아용품, 음. 식료품, 각종서비스 등에서 인터넷 쇼핑을 뛰어 넘어서 24.2조 원을 기록하였고 전년대비 $63.8 \%$ 성장한 것으로 나타났다.

정보전달의 속도가 급속하게 진행되고 있는 ICT산업 기반 시대를 살아가고 있는 소비자들은 제품에 대한 정보를 직접 확인하고 구입할 수 있는 오프라인 쇼핑과, 정보화 기술의 디 지털 시대를 대표하는 인터넷을 통해 더 편리하게 쇼핑을 제 공하는 인터넷 쇼핑과 손아귀에 있는 스마트폰을 통해 언제 어디서나 실시간으로 상품정보를 확인하고 자신이 가장 선호 하는 상품을 구입할 수 있는 모바일 쇼핑 등이 공존하고 있는 다양한 구매경로를 통해 상품을 구입하며 자신의 상품구매 욕 구를 충족하게 된다.

스마트폰을 이용해 쇼핑하는 소비자들은 어떠한 서비스품질 을 만족하고 있기 때문에 상품 구입을 하는 것일까? 또한 그 들은 어떠한 서비스품질들로부터 얼마나 많은 편익을 얻을 수 있어서 스마트폰 쇼핑에서 상품을 구매하는 것일까? 최근 스 마트폰 쇼핑의 애플리케이션품질에 대한 연구에서 소비자들이 원하는 편익은 쇼핑의 즐거움, 신속한 접속, 사용상 편리성, 환불 및 불편한 대처 방안 명시 등이었고(Choi, 2012a; Wang \& Yum, 2015), 또한 고객의 이익우선 및 제안수렴, 약속준수 와 명성신뢰, 화면의 디자인 및 구성, 고객정보 보호 등의 순 으로(Choi, 2012b; Wang \& Yum, 2015) 나타났다.

현재 스마트폰을 활용한 쇼핑의 서비스품질에 대한 연구는 Parasuraman, Zeithaml, and Berry(1988)의 SERVQUAL(Choi, 2012b), Parasuraman, Zeithaml, and Malhotra(2005)의 e-서비 스품질(Choi, 2012a; Wang \& Yum, 2015), 일반적인 서비스품 질(Kim, 2017) 등을 고객만족의 선행변수로 사용하고 있다. 특 히 스마트폰 쇼핑의 서비스품질이 고객만족에 영향을 미치는 것에 대한 연구에서 Choi(2012a)는 스마트폰 특성은 유희성 (쇼핑 즐거움), e-서비스품질은 효율성(신속 접속, 사용 편리 등), e-서비스회복은 책임(환불, 불편한 대처 방안 명시 등) 등 이 영향을 미치는 것으로 분석하였고, Choi(2012b)는 공감성 (고객의 이익우선 및 제안수렴), 확신성(약속준수, 명성신뢰), 유형성(화면의 디자인 및 구성) 등의 순으로 영향을 미치는 것 으로 분석하였으며, 또한 Wang and Yum(2015)은 효율성(편 리성, 신속한 거래 처리 등), 이행성(성실한 약속 수행 등), 프 라이버시(고객정보 보호 등) 등의 순으로 영향을 미치는 것으 로 분석하였다.

스마트폰 쇼핑은 스마트폰이 급속하게 보급되면서 일반화되 어가고 있는 추세에 있다. 이에 따라 스마트폰 쇼핑몰은 다양 한 e-서비스품질 중에서 이용자들이 요구하는 서비스품질이 무엇인가를 찾아내어 제공함으로써 새로운 유통채널로 자리잡 아가고 있다. 현재 스마트폰 이용자들은 쇼핑몰 이용에서 부정 확한 정보나 복잡한 사용 내용 등 뿐만 아니라 신속한 대응으 로 고객의 어려운 문제를 해결하여야 하지만 지체되는 등 신 속한 정보처리와 같은 스마트폰의 장점을 살리지 못하고 있다. 따라서 우선 스마트폰 쇼핑몰이 스마트폰 쇼핑몰 이용자들에
게 맞춤형 서비스를 고객에게 제공하기 위해서 일반적인 서비 스품질들을 확장하고 다시 분류하여야 하고 이를 스마트폰 쇼 핑몰의 서비스품질 $\rightarrow$ 고객만족 $\rightarrow$ 행동의도의 경로구조로 분석 할 필요가 있다.

본 연구는 기존연구에서 적용하고 있는 스마트폰 쇼핑몰의 서비스품질, 인터넷 쇼핑몰과 서비스산업의 서비스품질, Lee (2002)의 e-SERVQUAL, 그리고 Parasuraman et al.(1988)과 Parasuraman et al.(2005)의 SERVQUAL과 E-S-QUAL 등을 바탕으로 스마트폰 쇼핑몰 이용자의 서비스품질들을 분류하고 지나치게 서비스부문으로만 좁혀져 서비스품질을 분류하고 있 는 기존연구와 비교하는 것을 목적으로 한다. 또한 스마트폰 이용자들을 대상으로 스마트폰 쇼핑몰의 서비스품질 $\rightarrow$ 고객만 족 $\rightarrow$ 행동의도 등의 경로구조를 검증하여 분류된 스마트폰 쇼 핑몰 서비스품질에 대한 일반화를 확인하는 것에 있다.

\section{2. 이론적 배경}

\section{1. 서비스품질}

품질(quality)은 여러 관점이 있지만 소비자 중심으로 설명하 면 "제품이나 서비스의 사용에서 소비자의 기대에 부응하는 마케팅, 기술-제조 및 보전에 관한 여러 가지 특성의 전체적 인 구성을 뜻한다"(Fregenbaum, 1983)라고 할 수 있다(Lee, 1999). 역시 서비스품질도(Yi, 2005) 사용자 중심에서“특정 소 비자에게 최대의 만족을 제공하는 상품특성의 최적결합인 이 상점의 개념"을 의미한다. 이것은 소비자의 선호를 가장 잘 만 족시켜주는 상품이 가장 높은 품질을 가진 것으로 간주되는 것을 의미한다(Yang \& Shim(2017)에서 재인용).

전통적으로 서비스품질은 유형성, 신뢰성, 반응성, 확신성, 공감성 등 5개로 구성된 SERVQUAL(1980년대) $\rightarrow$ 수정 SERVQUAL과 SERVPERF(1990년대)를 사용하고 있고, 이를 바탕으로 하는 기존연구는 서비스품질 $\rightarrow$ 지각가치 $\rightarrow$ 고객만족 $\rightarrow$ 행동의도(Tsou \& Liao, 2010; Raza, Siddiquei, Awan, \& Bukhari, 2012)와 서비스품질 $\rightarrow$ 고객만족 $\rightarrow$ 행동의도(Qin \& Prybutok, 2008; Cho \& Shine, 2009; Edward \& Sahadev, 2011) 등으로 구분할 수 있다. 한편 온라인 거래가 활성화됨 에 따라 이 산업의 온라인 서비스품질은 Parasuraman et al. (2005)의 E-S-QUAL과 Lee(2002)의 e-SERVQUAL 등으로 개 발되어 온라인 쇼핑몰에서 전자는 효율성, 시스템 이용가능성, 이행성, 프라이버시, 공감 등의 서비스품질 $\rightarrow$ 고객만족 $\rightarrow$ 행동의 도(Wang \& Yum, 2015; Choi, 2012a; Kim, Leem, \& Jang, 2011)로, 후자는 정보, 거래, 디자인, 의사소통, 안정성 등의 서비스품질 $\rightarrow$ 고객만족 $\rightarrow$ 행동의도(Choi \& Kang, 2009) 등의 경로구조로 연구되고 있다.

본 연구와 관계가 있는 국내외 스마트폰 쇼핑몰의 서비스품 질에 관한 기존연구는 Parasuraman et al.(2005)의 E-S-QUAL 과 Lee(2002)의 e-SERVQUAL, 전통적인 Parasuraman et al. (1985, 1988, 1991)의 SERVQUAL을 근거로 분류한 e-서비스 품질 $\rightarrow$ 고객만족 $\rightarrow$ 행동의도의 경로구조로 이루어지고 있다. 우선 Wang and Yum(2015)은 스마트폰 쇼핑몰의 e-서비스품 질을 Parasuraman et al.(2005)의 E-S-QUAL인 효율성, 시스템 이용가능성, 이행성, 프라이버시, 공감 등으로 나누고 E-S-서 비스품질들과 고객만족, 고객만족과 충성도와의 관계를 분석하 
였다. 둘째, Choi(2012a)는 여행 애플리케이션 서비스품질을 Parasuraman et al.(2005)의 E-S-QUAL과 E-Recs-QUAL인 책 임, 보상, 접촉, 그리고 콘텐츠에 유희성, 디자인, 정보성 등으 로 나누고 서비스 품질들과 고객만족, 고객만족과 재사용의도 와의 관계를 분석하였다. 마지막으로 Choi(2012b)는 외식기업 스마트폰 애플리케이션 서비스 품질을 전통적인 서비스 품질 인 유형성, 신뢰성, 응답성, 확신성, 공감성 등으로 나누고 서 비스 품질들과 고객만족, 고객만족과 재이용의도와의 관계를 분석하였으며, $\operatorname{Kim}(2017)$ 은 외식기업에서 스마트폰 애플리케 이션 서비스 품질을 시스템품질, 정보품질, 서비스품질 등으로 나누고 스마트폰 $\mathrm{O} 2 \mathrm{O}($ Online to Offline)의 서비스품질들과 고 객만족과의 영향 관계를 분석하였다.

따라서 본 연구는 기존연구에서 적용하고 있는 스마트폰 쇼 핑몰의 서비스품질, 인터넷 쇼핑몰과 서비스산업의 서비스품 질, Lee(2002)의 e-SERVQUAL, 그리고 Parasuraman et al. (1988)과 Parasuraman et al.(2005)의 SERVQUAL과 E-S-QUAL 등을 바탕으로 스마트폰 쇼핑몰 이용자의 서비스품 질들을 시스템 품질, 편의성 품질, 웹디자인 품질, 상품 품질, 정보제공 품질, 고객서비스 품질 등으로 분류하고 관련 차원의 측정항목을 개발한다. 또한 이들 측정항목들이 일반적으로 적 용 가능한지 확인하기 위해서 실증을 통해 스마트폰 쇼핑몰의 서비스품질 $\rightarrow$ 고객만족 $\rightarrow$ 행동의도의 경로구조로 서비스품질 과 고객만족과의 관계를 분석하기로 한다.

\section{2. 고객만족}

고객만족은 상품이나 서비스의 품질에 대한 기대가 충족되 어 나타나는 감정상태로 재구입의 가능성을 높여 상품에 대한 충성도까지 이르게 되는 상태를 말한다. 특히 서비스산업을 대 상으로 하는 국내외의 고객만족에 대한 기존연구는 고객만족 이 Parasuraman et al.(1985, 1988, 1991)의 SERVQUAL과 수 정 SERVQUAL, 그리고 Cronin and Taylor(1992)의 SERVPERF 등을 바탕으로 하는 결과변수로 서비스품질에 의 해 영향을 받고 있음을 보여준다(Park \& Lee, 2013; Prabha, 2012; Tsou \& Liao 2010). 인터넷과 같은 온라인 쇼핑몰 이용 자의 고객만족에 관한 기존연구에서도 e-서비스품질 $\rightarrow$ 고객만 족 $\rightarrow$ 행동의도(Lee \& LIn, 2005; Cho, 2009)에서 고객만족은 서비스품질의 선행변수로부터 영향을 받고 있음을 보여준다.

한편 스마트폰 쇼핑몰을 이용하는 소비자의 고객만족에 관 한 국내외의 기존연구는 고객만족이 Parasuraman et al.(1985, 1988)의 SERVQUAL과 Parasuraman et al.(2005)의 E-S-QUAL을 바탕으로 하는 다양한 서비스품질에 의해 영향 받 고 있다는 것을 아래와 같이 보여주고 있다(Kim, 2017; Wang \& Yum, 2015; Choi, 2012a; Choi, 2012b; Lee, 2012). 우선 $\mathrm{Kim}(2017)$ 은 외식산업의 스마트폰 $\mathrm{O} 2 \mathrm{O}$ 서비스APP품질을 시 스템품질, 정보품질, 서비스품질 등으로 나누었고, 고객만족이 서비스APP품질들에 의해 각각 정(+)의 영향을 받고 있음을 분 석하였다. 또한 고객만족은 서비스APP품질에 지각된 유용성과 용이성에 의해 각각 정(+)의 영향을 받고 있음을 분석하였다. 둘째, Wang and Yum(2015)는 스마트폰 뱅킹의 서비스품질이 고객만족에 미치는 영향을 연구하면서 서비스품질을 Parasuraman et al.(2005)의 E-S-QUAL을 기반으로 하는 효율 성, 시스템 이용가능성, 이행성, 프라이버시, 공감 등으로 나누 었고, 고객만족이 서비스품질들 중 효율성, 이행성, 프라이버 시 등에 의해 각각 정(+)의 영향을 받고 있음을 분석하였다.
셋째, Choi(2012a)는 여행 애플리케이션 e-서비스품질을 효율 성, 실행성, 신뢰성, 보안성 등으로 나누었고, 고객만족이 e-서 비스품질들 중 효율성, 실행성, 신뢰성 등에 의해 각각 정(+)의 영향을 받고 있음을 분석하였다. 넷째, Choi(2012b)는 외식기 업 스마트폰 애플리케이션 서비스품질을 유형성, 신뢰성, 응답 성, 확신성, 공감성 등으로 나누었고, 고객만족이 서비스품질 들 중 유형성, 확신성, 공감성 등에 의해 각각 정(+)의 영향을 받고 있음을 분석하였다. 마지막으로 Lee(2012)는 스마트폰 서비스품질을 통화품질, 단말기품질, 부가서비스, 고객지원 등 을 통합하여 인지품질로 측정하고, 고객만족이 인지품질에 의 해 정(+)의 영향을 받고 있음을 분석하였다.

따라서 본 연구는 기존연구에서 적용하고 있는 스마트폰 쇼 핑몰의 서비스품질을 바탕으로 스마트폰 쇼핑몰을 이용하는 사용자의 고객만족이 다양한 서비스품질들에 의해 영향 받고 있다는 것을 실증적으로 분석한다. 또한 스마트폰 쇼핑몰 이용 자의 고객만족이 다양하게 분류된 서비스품질에 의해 영향 받 고 있다는 것을 확인하기 위해서 스마트폰 쇼핑몰의 서비스품 질 $\rightarrow$ 고객만족 $\rightarrow$ 행동의도의 경로구조로 분석한다.

\section{3. 행동의도}

상품의 다양한 품질을 경험한 소비자는 자신의 기대와 일치 할 때 고객만족을 하면 구매 후 평가로 긍정 행동을 보이게 된다. 이러한 긍정적 행동은 구매 상품에 대해 재구입할 수 있 는 의도를 가질 수 있게 하고 반복된 재구입 행동은 구입한 상 품에 대한 충성도로 나타나 타인에게 추천하는 구전의도로 나 타나게 된다.

스마트폰 쇼핑몰의 e-서비스 품질(또는 APP 특성) $\rightarrow$ 고객만 족 $\rightarrow$ 행동의도에 대한 경로구조의 기존연구에서 사용된 행동 의도는 행동의도(Kim \& Jeon, 2016; Jung \& Kim, 2014), 충 성도(Lee \& Baek, 2017; Wang \& Yum, 2015; Jung \& Lee, 2013), 재이용의도(Cho, Song, \& Jeon, 2016; Choi, 2012a; Choi, 2012b; Shen, 2014; Kim, Leem, \& Jang, 2011) 등으로 나타나고 있다.

따라서 본 연구는 일반 온라인과 스마트폰 쇼핑몰을 대상으 로 하는 기존연구에서 사용한 서비스품질, SERVQUAL(1988)과 E-S-QUAL(2005)의 서비스품질 등을 바탕으로 스마트폰 쇼핑몰 의 서비스품질 $\rightarrow$ 고객만족 $\rightarrow$ 행동의도의 경로구조에서 고객만족 이 행동의도에 어떻게 영향을 미치는지 그 관계를 분석한다.

\section{4. 신로}

온라인 거래는 오프라인 거래와 달리 공급자에 의해 제공된 정보와 사이트에 진열된 상품을 보고 구매의사결정을 하는 교 환이기 때문에 소비자는 공급자에 대한 호의적인 기대에 근거 한 믿음인 신뢰(trust)를 통해 보다 긍정적인 구매 결정을 하게 성립된다.

서비스산업에서 신뢰가 고객만족과 행동의도 사이에서 매개 (Jang, 2007), 조절(Cho \& Shine, 2009)하는 것으로 나타났다. 또한 인터넷 쇼핑몰에서도 신뢰가 고객만족과 행동의도(재이 용의도와 추천의도) 사이에서 조절되어 재이용의도와 추천의 도에 각각 영향을 미치는 것으로 분석되었다(Cho, 2009; Cho \& Kang, 2009).

스마트폰 쇼핑몰 거래할 때 신뢰에 관한 연구에서 신뢰는 행동의도에 영향을 미치는 것으로 나타났다. Choi and Choi 
(2011)은 스마트폰 애플리케이션 품질에서 영향을 받은 신뢰 가 지속적인 사용의도에 정(+)의 영향을 미치는 연구를 하였 고, Chang and $\mathrm{Kim}(2012)$ 는 프로구단의 스마트폰 애플리케이 션 서비스품질에서 영향을 받은 신뢰가 구단충성도에 정(+)의 영향을 미치는 연구를 하였으며, Lee(2013)은 지각된 스마트 폰 앱스토어의 정보와 시스템품질에서 영향을 받은 앱스토어 신뢰가 앱스토어의 지속적 이용에 정(+)의 영향을 미치는 연구 를 각각 하였다.

따라서 본 연구는 스마트폰 쇼핑몰의 서비스품질들이 고객 만족에 영향을 미치고, 이 고객만족과 행동의도와의 영향관계 에서 신뢰에 의해 조절되는지를 검증하기로 한다.

\section{3. 가설설정}

\section{1. 서비스품질과 고객만족과의 관계}

스마트폰 쇼핑몰의 시스템 품질은 스마트폰 쇼핑몰의 빠른 접속 및 응답과 같은 안정적인 시스템을 가진 접속환경을 말 하는 것으로 이 품질이 고객만족에 영향을 미치고 있는 것으 로 분석되었다(Kim, 2017; Cho et al., 2016; Kim \& Jeon, 2016; Choi, 2012a). 특히 접속의 편리성과 빠른 속도, 화면 이동의 편리성, 시스템의 안전성, 항상 이용 가능성 등이 고객 만족에 정(+)의 영향을 미치는 것으로 나타났다. 따라서 본 연 구는 위에서 언급한 시스템 품질과 고객만족과의 영향 관계에 대해 가설 1 을 아래와 같이 설정한다.

H1: 시스템 품질은 고객만족에 대해 정(+)의 영향을 미칠 것이다.

스마트폰 쇼핑몰의 웹디자인 품질은 다른 스마트폰 쇼핑몰 의 사이트와 구별이 될 정도의 전문성에 적합한 색상과 디자 인, 이용에 편리한 컨텐츠와 화면 구성 등과 같은 것으로 이 품질이 고객만족에 영향을 미치고 있는 것으로 분석되었다 (Kim, 2017; Cho et al., 2016; Choi, 2012a; Choi, 2012b). 특 히 깨끗한 디자인, 시각적으로 좋은 디자인, 적절한 글과 그림 배치, 사용에 친숙한 디자인 등이 고객만족에 정(+)의 영향을 미치는 것으로 나타났다. 따라서 본 연구는 위에서 언급한 웹 디자인 품질과 고객만족과의 영향 관계에 대해 가설 2를 아래 와 같이 설정한다.

H2: 웹디자인 품질은 고객만족에 대해 정(+)의 영향을 미칠 것이다.

스마트폰 쇼핑몰의 편리성 품질은 누구나 쇼핑몰에 쉽게 접 근하여 원하는 상품을 편리하게 구입할 수 있는 상품의 위치, 메뉴구조, 그리고 화면 분위기 등의 사용방식으로 이 품질이 고객만족에 영향을 미치고 있는 것으로 분석되었다(Kim, 2017; Cho et al., 2016; Kim \& Jeon, 2016; Choi, 2012a). 특히 화 면구성의 편리성, 검색과 선택의 편리성, 정보탐색의 편리성, 접속의 편리성 등이 고객만족에 정(+)의 영향을 미치는 것으로 나타났다. 따라서 본 연구는 위에서 언급한 편리성 품질과 고 객만족과의 영향 관계에 대해 가설 3 을 아래와 같이 설정한다.

H3: 편리성 품질은 고객만족에 대해 정(+)의 영향을 미칠 것이다.
인터넷 쇼핑몰의 상품품질은 눈으로 확인한 다양한 브랜드 및 상품의 품질, 배달된 품질과 비교하거나 상품의 구성 및 가 격 등에 대한 것으로 이 품질이 고객만족에 영향을 미치고 있 는 것으로 분석되었다(Yang \& Shim, 2017). 특히 다양한 상품 구색, 타 거래보다 싼 상품의 가격, 표시된 것과 동일한 배달 상품 등이 고객만족에 정(+)의 영향을 미치는 것으로 나타났 다. 따라서 본 연구는 위에서 언급한 상품품질과 고객만족과의 영향 관계에 대해 가설 4 를 아래와 같이 설정한다.

\section{H4: 상품품질은 고객만족에 대해 정(+)의 영향을 미칠 것이다.}

스마트폰 쇼핑몰의 고객서비스 품질은 쇼핑을 전후하여 제 공되는 쇼핑몰의 인적 및 비인적 모든 서비스로 문제해결, 응 답태도, 보안성 등으로 이 품질이 고객만족에 영향을 미치고 있는 것으로 분석되었다(Kim, 2017; Cho et al., 2016; Kim \& Jeon, 2016; Wang \& Yum, 2015; Choi, 2012a; Choi, 2012b; Lee, 2012). 특히 보안성, 실행성, 신뢰성, 효율성, 응답성, 심 미성 등이 고객만족에 정(+)의 영향을 미치는 것으로 나타났 다. 따라서 본 연구는 위에서 언급한 고객서비스 품질과 고객 만족과의 영향 관계에 대해 가설 5 를 아래와 같이 설정한다.

H5: 고객서비스 품질은 고객만족에 대해 정(+)의 영향을 미 칠 것이다.

스마트폰 쇼핑몰의 정보제공 품질은 소비자들이 구매에 정 확한 의사결정을 할 수 있는 상품정보의 풍부성 및 신속성 등으로 이 품질이 고객만족에 영향을 미치고 있는 것으로 분 석되었다(Kim, 2017; Cho et al., 2016; Kim \& Jeon, 2016; Choi, 2012a). 특히 정확한 상품 정보 제공, 최신 정보 제공, 이해하기 쉬운 정보 제공, 다양한 정보 제공, 안전한 거래정보 제공 등이 고객만족에 정(+)의 영향을 미치는 것으로 나타났 다. 따라서 본 연구는 위에서 언급한 정보제공 품질과 고객만 족과의 영향 관계에 대해 가설 6 을 아래와 같이 설정한다.

H6: 정보제공 품질은 고객만족에 대해 정(+)의 영향을 미칠 것이다.

\section{2. 고객만족과 행동의도와의 관계}

소비자는 다양한 상품의 품질을 경험함과 함께 자신의 기대 와 일치하여 고객만족을 할 때 구매 후 재구매의도와 같은 긍 정적 행동을 하게 된다. 스마트폰 쇼핑몰의 서비스품질에 만족 한 소비자들은 행동의도에 영향을 미치는 것으로 나타났다. 특 히 스마트폰 쇼핑몰을 이용한 후 만족한 소비자는 행동의도 (Kim \& Jeon, 2016; Jung \& Kim, 2014)에 정(+)의 영향을 미 치고 있는 것으로 분석되었다. 또한 스마트폰의 쇼핑몰을 이용 한 소비자는 충성도(Lee \& Baek, 2017; Wang \& Yum, 2015; Jung \& Lee, 2013), 재이용의도(Cho, Song, \& Jeon, 2016; Shen, 2014; Choi, 2012a; Choi, 2012b; Kim, Leem, \& Jang, 2011) 등에 각각 정(+)의 영향을 미치는 것으로 나타났다.

따라서 본 연구는 스마트폰 쇼핑몰의 지속적인 이용, 다시 이용할 예정, 더 높은 가격 지불, 타인들에게 긍정적인 설명, 주변 친지들에게 적극 추천, 타인에게 우선 추천 등의 항목을 바탕으로 고객만족과 행동의도와의 영향 관계에 대해 가설7을 아래와 같이 설정한다.

$\mathrm{H7}$ : 고객만족은 행동의도에 대해 정(+)의 영향을 미칠 것이다. 


\section{3. 고객만족과 행동의도, 신뢰와의 관계}

온라인 거래는 오프라인거래와 달리 공급자에 대한 호의적 인 기대에 근거한 믿음인 신뢰(trust)를 통해 성립된다. 인터넷 쇼핑몰에서 여러 서비스품질을 통해 만족한 소비자들은 신뢰 수준이 높을수록 고객만족과 재이용의도, 고객만족과 추천의도 간의 관계가 각각 높은 것으로 나타났다(Cho, 2009; Cho \& Kang, 2009).

스마트폰 쇼핑몰 거래에서 신뢰는 행동의도에 영향을 미치 는 것으로 나타났다. 스마트폰 애플리케이션 품질에서 영향을 받은 신뢰가 지속적인 사용의도(Choi \& Choi, 2011)에, 서비스 품질에서 영향을 받은 신뢰가 충성도(Chang \& Kim, 2012)에, 시스템품질에서 영향을 받은 앱스토어 신뢰가 앱스토어의 지 속적 이용(Lee, 2013)에 각각 정(+)의 영향을 미치는 것으로 나타났다.

따라서 본 연구는 스마트폰 쇼핑몰의 정확한 거래내력, 개 인 신상정보 보호, 일관된 운영방식, 안정적인 온라인 거래 등 의 항목을 바탕으로 신뢰수준이 높을수록 고객만족과 행동의 도와의 영향 관계에 대해 가설 8 을 아래와 같이 설정한다.

H8: 신뢰수준이 높을수록 고객만족과 행동의도 간의 관계는 강해질 것이다.

\section{4. 연구모형}

본 연구는 스마트폰 쇼핑몰의 기존연구에서 사용되고 있는 서비스품질을 기반으로 시스템 품질, 웹디자인 품질, 상품 품 질, 편의성 품질, 정보제공 품질, 고객서비스 품질 등으로 분 류한다. 이런 분류는 스마트폰 쇼핑몰의 기존연구에서 Parasuraman et al.(1988)과 Parasuraman et al.(2005)을 바탕 으로 하는 유무형의 서비스품질을 대부분 사용하고 있지만 이 를 포함해 다른 학자의 기존연구를 검토하여 보다 더 확장한 것이다.

따라서 본 연구는 스마트폰 쇼핑몰의 소비자를 대상으로 측 정항목을 새롭게 개발하고 이를 스마트폰 쇼핑몰의 서비스품 질 $\rightarrow$ 고객만족 $\rightarrow$ 행동의도의 경로구조를 검증하기 위해서 가 설을 <Figure 1>과 같이 설정하였다. 또한 고객만족과 행동의 도와의 영향관계에서 신뢰에 의해 조절되는지를 확인하기 위 해 조절효과를 분석하기로 한다.

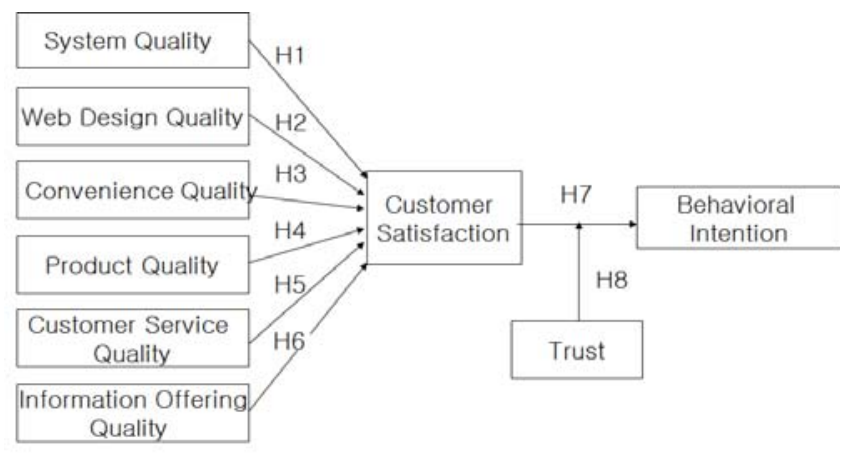

Figure 1: Research model

\section{4. 연구방법}

\section{1. 자료수집 및 분석방법}

본 연구의 설문지 조사는 2017년 12월 7일부터 12월 17일 까지 서울의 북동부지역에 위치한 대학교의 학생들을 대상으 로 실시하였다. 설문지는 총 240부를 배부하였고 228부의 설 문지가 회수되었다. 회수된 설문지 중 최종적인 연구에 사용 가능한 설문지는 총 201 부였으며 성의 없이 기재하여 연구에 사용할 수 없는 27 부는 제외되었다.

본 연구는 실증분석을 위해 통계패키지는 SPSS 18.0을 사 용하였고, 이를 사용하여 빈도분석, 요인분석, 상관관계분석, 단순 및 다중회귀분석, 조절회귀분석 등을 행하였다.

\section{2. 구성개념과 측정항목}

스마트폰 쇼핑몰의 서비스품질, 고객만족, 신뢰, 행동의도 등에 대한 측정항목들은 Parasuraman et al.(1988)과 Parasuraman et al.(2005), 온라인 거래의 기존연구에서 사용 한 변수들의 항목 등을 바탕으로 하고 있다. 이를 분석하여 Yang and Shim(2017)은 인터넷 쇼핑몰의 측정항목을 새롭게 구성하였는데 본 연구는 이를 스마트폰 쇼핑몰에 맞게 일부 반영하였으며, 이를 반영한 항목을 바탕으로 본 연구의 측정항 목을 설명하면 아래와 같다.

우선, 인터넷 쇼핑몰의 서비스품질들은 시스템 품질, 웹디자 인 품질, 편의성 품질, 상품 품질, 정보제공 품질, 고객서비스 품질 등 여섯 가지의 구성개념으로 구분하였고 다음과 같이 기존연구를 반영하여 측정항목들을 개발하였다. 첫째, 시스템 품질은 스마트폰 쇼핑몰의 접속환경, 다운로딩 속도, 빠른 검 색, 정보검색 용이성, 안정적인 시스템, 빠른 응답 속도, 좋은 보안시스템 등의 항목으로 구성되며, $\operatorname{Kim}(2017), \operatorname{Kim}$ and Jeon(2016), Li et al.(2013), Choi(2012a), Cho and Kang (2009), Lee and Lin(2005), Jang et al.(2005), Lim(2005), $\mathrm{Lee}(2002)$ 등의 측정항목을 고려하였다. 둘째, 웹디자인 품질 은 스마트폰 쇼핑몰의 이용에 적합한 디자인, 타 사이트와 차 이 나는 디자인, 이용에 적합한 색상, 사이트의 전문성 보유, 용이한 컨텐츠 이동, 깔끔한 디자인, 적절한 구성 배치 등의 항목으로 구성되며, Kim and Jeon(2016), Li et al.(2013), Yoon(2012), Choi(2012a), Cho and Kang(2009), Lee and Lin (2005), Lim(2005), Ahn and Lee(2002), Lee(2002) 등의 측정 항목을 고려하였다. 셋째, 편리성 품질은 사용하기 쉬운 메뉴 구조, 용이한 상품의 위치 파악, 알기 쉬운 화면 구성, 간편한 사용방법, 용이한 사이트 파악, 쉬운 상품구매, 쇼핑시간 단축, 일관적인 정보 제공, 조화 있는 화면 분위기 등의 항목으로 구 성되며, Kim(2017), Kim and Jeon(2016), Li et al.(2013), Yoon(2012), Choi(2012a), Cho and Kang(2009), Ahn and Lee(2002) 등의 측정항목을 고려하였다. 넷째, 상품 품질은 스 마트폰 쇼핑몰의 상품에 대한 종류와 품질과 관련하여 각종 상표로 구성, 능숙한 상품 업데이트, 각종 상품으로 구성, 적 정한 상품 가격, 양질의 상품 판매, 화면과 배달된 상품과 동 일한 품질 등의 항목으로 구성되며, Yang and Shim(2017), Li et al.(2013), Yoon(2012), Jang et al.(2005), Ahn and Lee (2002), Lee(2002) 등의 측정항목을 고려하였다. 다섯째, 고객 서비스 품질은 스마트폰 쇼핑몰의 이용자에게 도움을 주는 관 
리자, 보안유지 하는 관리자, 친절한 관리자, 문제해결 하는 관리자, 신속한 응대 서비스, 정확히 정보를 제공하는 관리자, 쇼핑을 유쾌하게 하는 관리자, 사후관리에 관심을 갖는 관리 자, 구매과정의 편의성을 제공하는 관리자 등의 항목으로 구성 되며, $\operatorname{Kim}(2017)$, Cho et al.(2016), Kim and Jeon(2016), Li et al.(2013), Jeun and Lee(2012), Lee and Lin(2005), Jang et al.(2005), Lim(2005), Ahn and Lee(2002), Lee(2002) 등의 측정항목을 고려하였다. 끝으로, 정보제공 품질은 스마트폰 쇼 핑몰의 신속한 최신정보 업데이트, 쇼핑정보 풍부하게 제공, 용이한 쇼핑정보 획득, 신속한 재구매 정보 제공, 상품의 정보 제공 등의 항목으로 구성되며, $\mathrm{Kim}(2017), \mathrm{Kim}$ and Jeon (2016), Li et al.(2013), Yoon(2012), Choi(2012a), Cho and Kang(2009), Lim(2005), Lee(2002) 등의 측정항목을 고려하였 다.

두 번째, 고객만족은 Kim and Shim(2017), Cho and Kang (2009)과 Lee and Lin(2005) 등의 항목을 반영하여 “전반적인 만족”만을 단일항목으로 고려하였다. 세 번째, 행동의도는 Shang, Chen, and Kim(2017), Kim and Jeon(2016), Choi (2012a), Kim(2012), Cho and Kang(2009), Choi et al.(2008), Lee and Lin(2005), Kwon et al.(2003) 등의 항목을 고려하였 다. 마지막으로 신뢰는 $\mathrm{Kim}$ and Cho(2013), Yoon(2012), Chang and Kim(2012), Choi and Choi(2011), Cho and Kang (2009), Kwon et al.(2003), Ahn and Lee(2002) 등의 항목을 고려하였다.

한편 본 연구는 설문항목을 (1) 전혀 그렇지 않다, (2), (3), (4) 보통이다, (5), (6), (7) 매우 그렇다 등인 리커트(Likert) 7점
척도로 측정하였다.

\section{5. 결과분석}

\section{1. 표본의 특성}

표본 특성은 인구통계학적 변수와 스마트폰 쇼핑몰 이용특 성 변수로 나누어 <Table 1>과 같이 각각 특성을 조사하였다. 우선, 인구통계학적 변수는 성별은 남성 $52.7 \%$, 거주지역은 서울강북지역 $25.9 \%$ 와 경기남부지역 $23.9 \%$, 월평균 용돈은 30 만원-40만원 미만 $28.9 \%, 20$ 만원-30만원 미만 $27.4 \%$, 월평 균 스마트폰 쇼핑비용은 10 만원 미만 $71.6 \%$ 등으로 각각 높 은 비중을 보여주고 있다. 특히 월평균 스마트폰 쇼핑비용은 대학생들의 월평균 20 만 원-40만 원 용돈 중 상당한 금액을 스마트폰 쇼핑으로 이용하고 있는 것으로 나타났다. 둘째, 스 마트폰 쇼핑몰 이용특성 변수는 선택이유로 상품가격 $52.7 \%$, 자주 이용한 스마트폰 쇼핑몰은 기타 $33.8 \%, 11$ 번가 $19.4 \%$, 쿠팡 $18.4 \%$, 월 이용회수는 2-3회가 $44.8 \%$, 정보획득은 스마 트폰 $32.3 \%$, 인터넷 $26.4 \%$, 이용목적은 상품구매 $62.7 \%$ 등으 로 높은 비중을 보여 주고 있다. 이 두 변수들은 이용횟수, 정 보획득 등에 나타난 것처럼 스마트폰 쇼핑몰의 이용 특성을 잘 반영하고 있는 것으로 나타났다. 위와 같이 살펴본 것처럼 이 두 가지 변수들은 스마트폰 쇼핑몰 이용자들의 특성을 충 분히 반영하고 있음을 보여주고 있다.

Table 1: General characteristics of sample

\begin{tabular}{|c|c|c|c|c|c|c|c|}
\hline \multicolumn{2}{|r|}{ Category } & \multirow{3}{*}{$\begin{array}{c}\begin{array}{c}\text { Freq. } \\
\mathbf{N}=201\end{array} \\
106 \\
95\end{array}$} & \multirow{3}{*}{$\begin{array}{c}\begin{array}{c}\text { Weight } \\
\text { (\%) }\end{array} \\
52.7 \\
47.3\end{array}$} & \multicolumn{2}{|r|}{ Category } & \multirow{2}{*}{$\begin{array}{c}\begin{array}{c}\text { Freq. } \\
\mathrm{N}=201\end{array} \\
23\end{array}$} & \multirow{2}{*}{$\begin{array}{c}\begin{array}{c}\text { Weight } \\
\text { (\%) }\end{array} \\
11.4\end{array}$} \\
\hline Gender & Male & & & \multirow{6}{*}{$\begin{array}{l}\text { Reason for } \\
\text { selection }\end{array}$} & \multirow{6}{*}{$\begin{array}{l}\text { Quality of goods } \\
\text { Price of goods } \\
\text { Excellent Web-design } \\
\text { Staff service } \\
\text { Brand reputation } \\
\text { Others }\end{array}$} & & \\
\hline Gender & Female & & & & & 106 & 52.7 \\
\hline \multirow{6}{*}{$\begin{array}{l}\text { Residential } \\
\text { area }\end{array}$} & Southern area of Seoul & 36 & 17.9 & & & 4 & 2.0 \\
\hline & Northern area of Seoul & 52 & 25.9 & & & 26 & 12.9 \\
\hline & Incheon city & 11 & 5.5 & & & 14 & 7.0 \\
\hline & Northern area of Kyonggi & 34 & 16.9 & & & 28 & 13.9 \\
\hline & Southern area of Kyonggi & 48 & 23.9 & \multirow{10}{*}{$\begin{array}{l}\text { Frequently } \\
\text { used } \\
\text { smartphone } \\
\text { shopping } \\
\text { mall }\end{array}$} & G Market & 29 & 14.4 \\
\hline & Others & 20 & 10.0 & & $11 s t$ & 39 & 19.4 \\
\hline \multirow{5}{*}{$\begin{array}{l}\text { Allowance } \\
\text { per month } \\
\text { (thousand) }\end{array}$} & Less than 200 won & 40 & 19.9 & & Auction & 14 & 7.0 \\
\hline & 200 won-less than 300 won & 55 & 27.4 & & Coupang & 37 & 18.4 \\
\hline & 300 won-less than 400 won & 58 & 28.9 & & Lotte.com & 1 & 0.5 \\
\hline & 400 won-less than 500 won & 17 & 8.5 & & Hyundai mall & 4 & 2.0 \\
\hline & More than 500 won & 31 & 15.4 & & GS Shop & 3 & 1.5 \\
\hline \multirow{5}{*}{$\begin{array}{l}\text { Shopping } \\
\text { cost per } \\
\text { month } \\
\text { (thousand) }\end{array}$} & Less than 100 won & 144 & 71.6 & & Interpark & 1 & 0.5 \\
\hline & 100 won-less than 150 won & 35 & 17.4 & & CJ mall & 5 & 2.5 \\
\hline & 150 won-less than 200 won & 12 & 6.0 & & Others & 68 & 33.8 \\
\hline & 200 won-less than 250 won & 3 & 1.5 & \multirow{6}{*}{$\begin{array}{l}\text { Information } \\
\text { acquisition }\end{array}$} & Word of mouth & 21 & 10.4 \\
\hline & More than 250 won & 7 & 3.5 & & Usage experience & 39 & 19.4 \\
\hline \multirow{8}{*}{$\begin{array}{c}\text { Times of } \\
\text { monthly } \\
\text { use }\end{array}$} & Less than 1 times & 53 & 26.4 & & Adv.(TV,News paper) & 17 & 8.5 \\
\hline & 2-3times & 90 & 44.8 & & Internet & 53 & 26.4 \\
\hline & 4-5times & 37 & 18.4 & & Smart Phone & 65 & 32.3 \\
\hline & More than 6times & 21 & 10.4 & & Others & 6 & 3.0 \\
\hline & & & & \multirow{4}{*}{$\begin{array}{c}\text { Purpose of } \\
\text { utilization }\end{array}$} & Purchase of goods & 126 & 62.7 \\
\hline & & & & & Search of product information & 36 & 17.9 \\
\hline & & & & & Search of product price information & 29 & 14.4 \\
\hline & & & & & Others & 10 & 5.0 \\
\hline
\end{tabular}




\section{2. 탐색적 요인분석과 신뢰성 분석}

본 연구는 타당성과 내적 일관성을 분석하기 위해서 탐색적 요인분석과 신뢰성 분석 등을 <Table 2>와 <Table 3>과 같이 선행변수와 결과변수로 나누어 조사하였다. 우선, 선행변수의 요인적재량은 사회과학의 기준을 충족하고 있는 것으로 나타 났다. 상품 품질과 웹디자인 품질의 측정항목 한 개가 각각 유 의한 변수로 인정되고 있는 0.5 이하였고(Chaiy, 1999), 나머 지 변수들의 측정항목들은 아주 중요한 변수로 인정되는 0.5 이상(Chaiy, 1999)이었다. 설명된 누적 총분산(\%)은 사회과학 기준으로 $60 \%$ 를 넘으면 설명력이 있는 것으로 평가되는데 본 연구는 $69.697 \%$ 로 나타나 설명력을 갖는 것으로 조사되었다. 또한, Cronbach's $\alpha$ 값은 구성개념 모두 바람직한 기준치라고 할 수 있는 0.828-0.911의 수치를 얻을 수 있어서 신뢰성 분 석은 구성개념 모두에서 상당히 높은 내적 일관성을 보여주고
있다. 하지만 본 연구의 요인분석에서 웹디자인 품질 $3(+1)$, 편리성 2(+2), 상품 품질 $3(+1)$, 고객서비스 품질 2, 정보제공 품질 5 등의 측정항목들을 제거하거나 2개는 다른 품질요인들 로 각각 묶이기도 하였다. 둘째, 결과변수의 요인적재량은 모 두 아주 중요한 변수로 인정되는 0.5 이상으로 나타나 사회과 학의 기준을 충족하고 있는 것으로 나타났다. 설명된 누적 총 분산(\%)은 $63.226 \%$ 로 나타나 사회과학기준 $60 \%$ 를 넘어 설명 력이 있는 것으로 조사되었다. 또한, Cronbach's $\alpha$ 값은 두 구 성개념 모두 바람직한 기준치라고 할 수 있는 신뢰와 행동의 도 각각 0.895 와 0.897 로 나타나 두 구성개념 모두 어느 정도 높은 내적 일관성을 보여주고 있다.

본 연구는 스마트폰 쇼핑몰의 서비스품질들을 분석한 결과, 서비스품질들은 시스템 품질, 편의성 품질, 웹디자인 품질, 상 품 품질, 정보제공 품질, 고객서비스 품질 등 여섯 가지로 분 류되었다.

Table 2: Results of the factor analysis and reliability of service qualities

\begin{tabular}{|c|c|c|c|c|c|}
\hline Factors & Items & $\begin{array}{l}\text { Factor } \\
\text { loading }\end{array}$ & $\begin{array}{l}\text { Eigen } \\
\text { value }\end{array}$ & $\begin{array}{c}\text { Variance } \\
\text { explained(\%) }\end{array}$ & Cronbach's $\alpha$ \\
\hline $\begin{array}{l}\text { System } \\
\text { Quality }\end{array}$ & $\begin{array}{l}\text { Providing proper downloading speed } \\
\text { Usefulness of relevant information search } \\
\text { Providing easy access environment } \\
\text { Providing fast response speed } \\
\text { Establishing good information security system } \\
\text { Possibility of fast search } \\
\text { Providing stable transaction system }\end{array}$ & $\begin{array}{l}0.767 \\
0.742 \\
0.710 \\
0.638 \\
0.636 \\
0.635 \\
0.559\end{array}$ & 4.968 & 15.526 & 0.911 \\
\hline $\begin{array}{l}\text { Customer } \\
\text { Service } \\
\text { Quality }\end{array}$ & $\begin{array}{l}\text { Manager making efforts for after-sales service } \\
\text { Manager making efforts for problem-solving } \\
\text { Manager making efforts for security maintenance } \\
\text { Manager providing convenience in the purchase } \\
\text { process } \\
\text { Manager correctly providing various information } \\
\text { Manager kind to customer } \\
\text { Manager enabling pleasant shopping }\end{array}$ & $\begin{array}{l}0.757 \\
0.738 \\
0.661 \\
0.619 \\
0.578 \\
0.562 \\
0.544\end{array}$ & 4.376 & 23.202 & 0.886 \\
\hline $\begin{array}{c}\text { Convenience } \\
\text { Quality }\end{array}$ & $\begin{array}{l}\text { Easy screen composition } \\
\text { Usefulness of grasping the overall site } \\
\text { Usefulness of locating desired products } \\
\text { Menu structure easy to use } \\
\text { Expressing with consistent information }\end{array}$ & $\begin{array}{l}0.746 \\
0.740 \\
0.699 \\
0.651 \\
0.637\end{array}$ & 4.073 & 41.931 & 0.909 \\
\hline $\begin{array}{l}\text { Information } \\
\text { Offering } \\
\text { Quality }\end{array}$ & $\begin{array}{l}\text { Providing abundant shopping information } \\
\text { Providing objectivistic information } \\
\text { Speedily providing repurchase information } \\
\text { Providing information helpful for decision-making } \\
\text { Usefulness of obtaining shopping information }\end{array}$ & $\begin{array}{l}0.745 \\
0.718 \\
0.609 \\
0.513 \\
0.512\end{array}$ & 3.348 & 52.394 & 0.829 \\
\hline $\begin{array}{l}\text { Product } \\
\text { Quality }\end{array}$ & $\begin{array}{l}\text { Constituting with various trademarks } \\
\text { Skillful product update } \\
\text { Various product composition } \\
\text { Generally harmonious screen environment }\end{array}$ & $\begin{array}{l}0.805 \\
0.762 \\
0.678 \\
0.490\end{array}$ & 3.265 & 62.596 & 0.856 \\
\hline $\begin{array}{c}\text { Web Design } \\
\text { Quality }\end{array}$ & $\begin{array}{l}\text { Proper configuration of Website layout } \\
\text { Design graphics appropriate for use } \\
\text { Design color appropriate for use } \\
\text { Easy method of use }\end{array}$ & $\begin{array}{l}0.622 \\
0.510 \\
0.508 \\
0.497\end{array}$ & 2.273 & 69.697 & 0.828 \\
\hline
\end{tabular}

Note: No. of Eliminated Items : Web design quality 3(+1), Convenience Quality 2(+2). Product Quality 3(+1), Customer service quality 2, Information offering quality 5 
Table 3: Results of the factor analysis and reliability of behavioral intention and trust

\begin{tabular}{|c|c|c|c|c|c|}
\hline Factors & Items & $\begin{array}{l}\text { Factor } \\
\text { loading }\end{array}$ & $\begin{array}{l}\text { Eigen } \\
\text { value }\end{array}$ & $\begin{array}{c}\text { Variance } \\
\text { explained(\%) }\end{array}$ & Cronbach's $\alpha$ \\
\hline Trust & $\begin{array}{l}\text { Consistent management style } \\
\text { Protection of personal information of individuals } \\
\text { Product reliability } \\
\text { Stable online transaction } \\
\text { Maintenance of accurate transactional information } \\
\text { Speedy delivery } \\
\text { Smooth refund and exchange }\end{array}$ & $\begin{array}{l}0.842 \\
0.792 \\
0.782 \\
0.772 \\
0.750 \\
0.704 \\
0.520\end{array}$ & 4.747 & 33.905 & 0.897 \\
\hline $\begin{array}{l}\text { Behavioral } \\
\text { Intention }\end{array}$ & $\begin{array}{l}\text { Shopping mall that can tell others positively } \\
\text { Shopping mall that can actively recommend to others } \\
\text { Shopping mall that can recommend first on other's request for } \\
\text { recommendation } \\
\text { Shopping mall that will re-access with no purchase } \\
\text { Continuously useable shopping mall } \\
\text { Priority selection of the shopping mall I used before } \\
\text { Shopping mall due for reuse }\end{array}$ & $\begin{array}{l}0.814 \\
0.795 \\
0.784 \\
0.693 \\
0.664 \\
0.637 \\
0.600\end{array}$ & 4.105 & 63.226 & 0.895 \\
\hline
\end{tabular}

Note: No. of Eliminated Items : Behavioral Intention 1

Table 4: Results of correlation and multicollinearity analysis

\begin{tabular}{|c|c|c|c|c|c|c|c|c|c|c|c|}
\hline Variables & $\begin{array}{l}\text { System } \\
\text { Quality }\end{array}$ & $\begin{array}{c}\text { Web } \\
\text { Design } \\
\text { Qality }\end{array}$ & $\begin{array}{c}\text { Convenience } \\
\text { Quality }\end{array}$ & $\begin{array}{c}\text { Product } \\
\text { Qality }\end{array}$ & $\begin{array}{c}\text { Customer } \\
\text { Service } \\
\text { Qality }\end{array}$ & \begin{tabular}{|c|} 
Information \\
Offering \\
Qality
\end{tabular} & Trust & $\begin{array}{l}\text { Customer } \\
\text { Satisfaction }\end{array}$ & $\begin{array}{l}\text { Behaviora } \\
\text { I Intention }\end{array}$ & Average & Sd. \\
\hline $\begin{array}{l}\text { System } \\
\text { Quality }\end{array}$ & 1 & & & & & & & & & 4.81 & 0.92 \\
\hline $\begin{array}{c}\text { Web Design } \\
\text { Quality }\end{array}$ & $0.770^{\star * *}$ & 1 & & & & & & & & 4.91 & 0.92 \\
\hline $\begin{array}{c}\text { Convenience } \\
\text { Quality }\end{array}$ & $0.684^{\star * *}$ & $0.674^{\star * *}$ & 1 & & & & & & & 4.97 & 1.02 \\
\hline $\begin{array}{l}\text { Product } \\
\text { Quality }\end{array}$ & $0.609^{\star \star *}$ & $0.662^{\star * *}$ & $0.682^{* * *}$ & 1 & & & & & & 5.08 & 0.98 \\
\hline $\begin{array}{l}\text { Customer } \\
\text { Service } \\
\text { Quality }\end{array}$ & $0.649^{\star \star *}$ & $0.556^{\star * *}$ & $0.659^{\star * *}$ & $0.525^{\star \star \star}$ & 1 & & & & & 4.60 & 0.83 \\
\hline $\begin{array}{c}\text { Information } \\
\text { Offering } \\
\text { Quality }\end{array}$ & $0.647^{\star * *}$ & $0.628^{* * *}$ & $0.583^{* * *}$ & $0.564^{\star * *}$ & $0.717^{\star * \star}$ & 1 & & & & 4.79 & 0.83 \\
\hline Trust & $0.704^{* * *}$ & $0.675^{\star \star \star}$ & $0.661^{* * *}$ & $0.600^{\star * *}$ & $0.673^{\star * *}$ & $0.685^{\star \star *}$ & 1 & & & 4.77 & 0.91 \\
\hline $\begin{array}{c}\text { Customer } \\
\text { satisfaction }\end{array}$ & $0.676^{\star \star *}$ & $0.660^{* * *}$ & $0.615^{\star \star *}$ & $0.578^{\star * \star}$ & $0.596^{\star * \star}$ & $0.667^{\star * *}$ & $0.691^{* * *}$ & 1 & & 4.88 & 1.04 \\
\hline $\begin{array}{l}\text { Behavioral } \\
\text { Intention }\end{array}$ & $0.689^{* * *}$ & $0.628^{\star * *}$ & $0.625^{\star * *}$ & $0.544^{\star \star *}$ & $0.591^{* * *}$ & $0.681^{\star * *}$ & $0.674^{\star \star *}$ & $0.654^{\star * *}$ & 1 & 4.77 & 0.93 \\
\hline
\end{tabular}

$\left(p^{\star}<0.1, p^{* \star}<0.05, p^{\star \star *}<0.01\right)$

\section{3. 상관관계 및 다중공선성 분석}

선행변수와 결과변수의 상관관계는 가설의 방향성과 다중공 선성을 확인하기 위해 <Table $4>$ 와 같이 분석하였고 다중공선 성은 공차한계(tolerance)와 분산팽창요인(VIF) 등을 <Table 6> 과 같이 분석하였다. 먼저, 상관관계는 가설의 방향과 동일한 정(+)의 상관성을 보여주고 있으며 유의의수준은 모두 0.01 로 나타났다. 다음으로 상관관계가 모두 0.5 0.7로 높아서 다중공 선성의 가능성을 보여주고 있어서 공차한계와 분산팽창요인을 <Table 6>와 같이 분석하였으며 다중공선성은 모두 없는 것으

\section{로 조사되었다.}

\section{4. 가설검정}

본 연구는 스마트폰 쇼핑몰의 서비스품질들과 고객만족, 고 객만족과 행동의도 등과의 관계를 가설검증하기 위해서 회귀 분석을 <Table $5>$ 와 <Table $6>$ 과 같이 각각 실시하였다. 분석 결과 시스템 품질, 웹디자인 품질, 정보제공 품질 등 가설 $\mathrm{H} 1$, $\mathrm{H} 2$ 와 $\mathrm{H6}$ 등은 각각 지지되었고, 편리성 품질, 상품 품질, 고 객서비스 품질 등 $\mathrm{H} 3, \mathrm{H} 4, \mathrm{H} 5$ 등은 지지되지 않았다. 또한 고 
객만족과 행동의도에 대한 가설 $\mathrm{H} 7$ 은 지지되었다.

우선, 시스템 품질과 고객만족과의 관계는 통계적 유의수준 $\mathrm{p}<0.05$ 에서 표준화계수 $=0.206, \mathrm{t}=2.512$ 로 정 $(+)$ 의 영향을 주는 것으로 나타나 가설 $\mathrm{H} 1$ 은 지지되었으며, 시스템 품질이 높으 면 높을수록 고객만족은 더 큰 것으로 분석되었다. 둘째, 웹디 자인 품질과 고객만족과의 관계는 통계적 유의수준 $\mathrm{p}<0.05$ 에 서 표준화계수 $=0.171, \mathrm{t}=2.106$ 으로 정 $(+)$ 의 영향을 주는 것으 로 나타나 가설 $\mathrm{H} 2$ 는 지지되었으며, 웹디자인 품질이 높으면 높을수록 고객만족은 더 큰 것으로 분석되었다. 마지막으로, 정보제공 품질과 고객만족과의 관계는 통계적 유의수준 $\mathrm{p}<0.00$ 에서 표준화계수 $=0.279, \mathrm{t}=3.793$ 으로 정(+)의 영향을 주 는 것으로 나타나 가설 $\mathrm{H} 6$ 은 지지되었으며, 정보제공 품질이 높으면 높을수록 고객만족은 더 큰 것으로 분석되었다.

그러나 편리성 품질의 가설 $\mathrm{H} 3$ (표준화계수=0.103, $\mathrm{t}=1.333$ ), 상품 품질의 가설 $\mathrm{H} 4$ (표준화계수 $=0.082, \mathrm{t}=1.191)$ 와 고객서비 스 품질의 가설 $\mathrm{H} 5$ (표준화계수 $=0.056, \mathrm{t}=0.745$ ) 등은 통계적 유 의수준을 충족하지 못해서 지지되지 않았다. 따라서 스마트폰 쇼핑몰에서는 편리성 품질, 상품 품질, 고객서비스 품질 등은 고 객만족에 각각 정(+)의 영향을 미치지 않는 것으로 분석되었다.

또한 고객만족과 행동의도와의 관계는 통계적 유의수준 $\mathrm{p}<0.00$ 에서 표준화계수 $=0.654, \mathrm{t}=12.194$ 로 정(+)의 영향을 주 는 것으로 나타나 가설 $\mathrm{H} 7$ 은 <Table 6>과 같이 지지되었으며, 고객만족이 크면 클수록 추천 또는 재이용의도는 더 높은 것으 로 분석되었다. 따라서 고객만족이 크면 클수록 행동의도가 더 높게 나타나서 자신이 이용한 스마트폰 쇼핑몰에 대해 친지나 친구들에게 추천하고 재이용할 의도가 높은 것으로 분석되었다.

한편, 스마트폰 쇼핑몰 이용자들은 정보제공 품질(표준화계 수=0.279), 시스템 품질(표준화계수=0.206), 웹디자인 품질(표 준화계수=0.171) 등의 순서대로 고객만족에 영향을 주는 것으 로 나타났다. 따라서 스마트폰 쇼핑몰 이용자들은 스마트폰 쇼
핑몰의 용이한 접속환경 및 빠른 응답속도, 웹사이트의 구성배 치 및 그래픽 등보다 스마트폰 쇼핑몰의 객관성 있고 신속하 며 풍부한 쇼핑 정보 품질을 더 중요하게 평가하는 것으로 분 석되었다.

\section{5. 고객만족과 행동의도 간의 관계에서 신뢰의 조절 효과}

스마트폰 쇼핑몰 이용자들은 스마트폰 쇼핑몰의 용이한 접 속환경 및 빠른 응답속도, 웹사이트의 구성배치 및 그래픽, 객 관적이고 신속하며 풍부한 쇼핑 정보 등 다양한 품질요인을 통한 만족으로 재이용하거나 타인에게 추천하는 것으로 나타 났다. 따라서 본 연구는 고객만족과 행동의도 간의 관계에서 <Table 7>과 같이 스마트폰 쇼핑몰의 신뢰가 조절변수로서 역 할하고 있는가를 실증하기 위해 조절회귀분석을 행하였다.

고객만족과 행동의도와의 관계에서 조절회귀분석 결과는 다 음과 같다. 고객만족과 행동의도와의 관계에서 모형1과 모형2 는 통계적으로 모두 유의적인 결과 $(\mathrm{p}<0.01)$ 를 얻어서 모형1의 고객만족과 행동의도와의 관계와 모형2의 신뢰, 행동의도를 포함하는 관계 모두 정(+)의 영향을 미치고 있는 것으로 분석 되었다. 그러나 모형3의 신뢰, 상호작용변수 등과의 관계에서 두 변수는 모두 행동의도에 영향을 미치지 않는 것으로 분석 되었다. 특히 모형3에서 설명력이 증가 $\left(\Delta R^{2}=0.001\right)$ 하고 회귀 방정식도 통계적으로 유의적이었지만 $(\mathrm{p}=0.000)$, 상호작용변수 인 고객만족 *신뢰가 통계적으로 유의적이지 않은( $\beta=-0.153$, $\mathrm{p}=0.752)$ 것으로 분석되었다. 따라서 스마트폰 쇼핑몰의 서비 스품질들에 의해 영향을 받은 스마트폰 쇼핑몰 이용자들의 고 객만족과 행동의도와 사이에서 신뢰는 조절하지 못하는 것으 로 분석되어 가설8은 지지되지 않았다.

Table 5: Results of Multiple Regression between Service Quality and Customer Satisfaction

\begin{tabular}{|c|c|c|c|c|c|c|c|c|c|}
\hline \multirow{2}{*}{$\begin{array}{l}\text { Dependent } \\
\text { Variable }\end{array}$} & \multirow{2}{*}{$\begin{array}{l}\text { Independent } \\
\text { Variable }\end{array}$} & \multicolumn{2}{|c|}{ Unstandardized Coefficients } & \multirow{2}{*}{$\begin{array}{l}\text { S.C. } \\
(\beta)\end{array}$} & \multirow{2}{*}{$\mathrm{t}$-value } & \multirow{2}{*}{ Sig. } & \multirow{2}{*}{$\begin{array}{l}\text { Toler } \\
\text {-ance }\end{array}$} & \multirow{2}{*}{ VIF } & \multirow{2}{*}{ Results } \\
\hline & & B & Std. error & & & & & & \\
\hline \multirow{7}{*}{$\begin{array}{l}\text { Customer } \\
\text { Satisfaction }\end{array}$} & (Constant) & -0.189 & 0.319 & & -0.593 & & & & \\
\hline & System Quality(H1) & 0.234 & 0.093 & 0.206 & 2.512 & 0.013 & 0.319 & 3.138 & Accepted \\
\hline & Web Design Quality(H2) & 0.194 & 0.092 & 0.171 & 2.106 & 0.036 & 0.325 & 3.074 & Accepted \\
\hline & Convenience Quality(H3) & 0.105 & 0.079 & 0.103 & 1.333 & 0.184 & 0.362 & 2.763 & Rejected \\
\hline & Product Quality(H4) & 0.088 & 0.074 & 0.082 & 1.191 & 0.235 & 0.449 & 2.229 & Rejected \\
\hline & Customer Service Quality(H5) & 0.071 & 0.095 & 0.056 & 0.745 & 0.457 & 0.381 & 2.626 & Rejected \\
\hline & Information Offering Quality(H6) & 0.353 & 0.093 & 0.279 & 3.793 & 0.000 & 0.396 & 2.525 & Accepted \\
\hline
\end{tabular}

Note: S.C. - Standardized coefficients

Table 6: Results of Simple Regression between Customer Satisfaction and Behavioral Intention

\begin{tabular}{|c|c|c|c|c|c|c|c|}
\hline \multirow{2}{*}{ Dependent Variable } & \multirow{2}{*}{ Independent Variable } & \multicolumn{2}{|c|}{ Unstandardized Coefficients } & \multirow{2}{*}{$\begin{array}{l}\text { S.C. } \\
(\beta)\end{array}$} & \multirow{2}{*}{ t-value } & \multirow{2}{*}{ Sig. } & \multirow{2}{*}{ Results } \\
\hline & & B & Std. error & & & & \\
\hline \multirow{2}{*}{$\begin{array}{c}\text { Behavioral } \\
\text { Intention(H7) }\end{array}$} & (Constant) & 1.941 & 0.237 & & 8.187 & 0.000 & \\
\hline & Customer Satisfaction & 0.580 & 0.048 & 0.654 & 12.194 & 0.000 & Accepted \\
\hline \multicolumn{8}{|c|}{$R^{2}=0.428\left(\right.$ Aj. $\left.R^{2}=0.425\right), F=148.686, p=.000$} \\
\hline
\end{tabular}

Note: S.C. - Standardized coefficients 
Table 7: Results of Moderating Regression Analysis of Trust between Customer Satisfaction and Behavioral Intention

\begin{tabular}{|c|c|c|c|c|c|c|c|c|c|c|}
\hline \multirow{2}{*}{ Hypothesis } & \multirow{2}{*}{ Model } & \multirow{2}{*}{ Classification } & \multicolumn{2}{|c|}{ Unstandardized Coefficients } & \multirow{2}{*}{$\begin{array}{l}\text { S.C. } \\
(\beta)\end{array}$} & \multirow{2}{*}{ t-value } & \multirow{2}{*}{ Sig. } & \multirow{2}{*}{$\mathbf{R}^{2}$} & \multirow{2}{*}{$\Delta R^{2}$} & \multirow{2}{*}{ Results } \\
\hline & & & B & Std. error & & & & & & \\
\hline \multirow{11}{*}{$\mathrm{H} 8$} & \multirow{2}{*}{1} & (Constant) & 1.941 & 0.237 & & 8.187 & 0.000 & \multirow{3}{*}{0.428} & \multirow{3}{*}{ - } & \multirow{11}{*}{ Rejected } \\
\hline & & Customer Satisfaction & 0.580 & 0.048 & 0.654 & 12.194 & 0.000 & & & \\
\hline & & $\mathrm{R}^{2}=0.428(\mathrm{~A}$ & $R^{2}=0.425$ & $148.686, p$ & 000 & & & & & \\
\hline & \multirow{3}{*}{2} & (Constant) & 1.148 & 0.251 & & 4.565 & 0.000 & \multirow{4}{*}{0.522} & \multirow{4}{*}{0.94} & \\
\hline & & Customer Satisfaction & 0.319 & 0.060 & 0.360 & 5.296 & 0.000 & & & \\
\hline & & Trust & 0.433 & 0.069 & 0.426 & 6.267 & 0.000 & & & \\
\hline & \multicolumn{7}{|c|}{$R^{2}=0.522\left(\right.$ Aj. $\left.R^{2}=0.518\right), F=108.283, p=.000$} & & & \\
\hline & \multirow{4}{*}{3} & (Constant) & 1.518 & 1.196 & & 1.269 & 0.206 & \multirow{4}{*}{0.523} & \multirow{4}{*}{0.001} & \\
\hline & & Customer Satisfaction & 0.241 & 0.255 & 0.271 & 0.943 & 0.347 & & & \\
\hline & & Trust & 0.355 & 0.258 & 0.348 & 1.372 & 0,172 & & & \\
\hline & & Customer Satisfaction ${ }^{*}$ trust & 0.016 & 0.051 & 0.153 & 0.317 & 0.752 & & & \\
\hline
\end{tabular}

Note1: Dependent Variable: Behavioral Intention

2: S.C. - Standardized coefficients

6. 결론

\section{1. 연구결과의 요약 및 시사점}

본 연구는 기존연구에서 적용하고 있는 스마트폿 쇼핑몰의 서비스품질, 인터넷 쇼핑몰과 서비스산업의 서비스품질, Lee (2002)의 e-SERVQUAL, 그리고 Parasuraman et al.(1988)과 Parasuraman et al.(2005)의 SERVQUAL과 E-S-QUAL 등을 바탕으로 스마트폰 쇼핑몰 이용자의 서비스품질들을 분류하고 지나치게 서비스부문으로만 좁혀져 서비스품질을 분류하고 있 는 기존연구와 비교하는 것을 목적으로 한다. 또한 스마트폰 이용자들을 대상으로 스마트폰 쇼핑몰의 서비스품질 $\rightarrow$ 고객만 족 $\rightarrow$ 행동의도 등의 경로구조를 검증하여 분류된 스마트폰 쇼 핑몰 서비스품질에 대한 일반화를 확인하는 것에 있다. 앞에서 실증한 연구결과를 요약하면 다음과 같다.

먼저, 스마트폰 쇼핑몰 서비스품질들을 기존연구에서 사용 되고 있는 스마트폰 쇼핑몰의 서비스품질, 인터넷 쇼핑몰과 서 비스산업의 서비스품질, Lee(2002)의 e-SERVQUAL, 그리고 Parasuraman et al.(1988)과 Parasuraman et al.(2005)의 SERVQUAL과 E-S-QUAL 등을 바탕으로 시스템 품질, 편의성 품질, 웹디자인 품질, 상품 품질, 정보제공 품질, 고객서비스 품질 등 여섯 가지 변수로 분류하였다. 본 연구는 스마트폰 쇼 핑몰 및 온라인 산업에 대한 기존연구의 e-SERVQUAL 등을 반영하여 분류한 스마트폰 쇼핑몰의 서비스품질들을 일반적으 로 서비스산업에서 사용되고(Kim, 2017; Cho et al., 2016; Kim \& Jeon, 2016; Wang \& Yum, 2015; Choi, 2012a; Choi, 2012b; Lee, 2012) 있는 유무형적인 모든 서비스품질들로 더 추가할 수 있다는 것을 확인할 수 있었다.

둘째, 스마트폰 쇼핑몰의 서비스품질들이 고객만족에 영향 을 주는 것으로 나타났다. 이를 보다 구체적으로 설명하면 다 음과 같다. 첫 번째, 시스템 품질은 고객만족에 정(+)의 영향을 미치는 것으로 나타났다. 시스템 품질이 높을수록 고객만족은 더 높은 것으로 나타났다. 즉 이것은 적절한 다운로드 속도로 빠른 응답 속도를 보이고 빠른 검색이 가능하여 용이한 접속
환경을 제공하기 때문이다. 또한 정보 보호를 위한 우수한 보 안시스템을 구축하여 안정된 거래시스템을 유지하고 있어서 스마트폰 쇼핑몰을 이용한 소비자는 시스템 품질에 대해 만족 하여 나타났다고 할 수 있다. 이 결과는 스마트폰 쇼핑몰의 시 스템 품질이 고객만족에 정(+)의 영향을 준다는 기존연구와 일 치한다(Kim, 2017; Cho et al., 2016; Kim \& Jeon, 2016). 두 번째, 웹디자인 품질이 고객만족에 정(+)의 영향을 미치는 것 으로 나타났다. 웹디자인 품질이 높을수록 고객만족이 더 높은 것으로 나타났다. 이것은 이용에 적합한 디자인 그래픽과 색상 으로 만들어 졌고 적절한 웹사이트 구성으로 배치되어 사용에 용이하여 나타났다고 할 수 있다. 이 결과는 스마트폰 쇼핑몰 의 웹디자인 품질이 고객만족에 정(+)의 영향을 준다는 기존연 구와 일치한다(Cho et al., 2016; Choi, 2012a; Choi, 2012b). 마지막으로 정보제공 품질이 고객만족에 정(+)의 영향을 미치 는 것으로 나타났다. 정보제공 품질이 높을수록 고객만족이 더 높은 것으로 나타났다. 이것은 객관적이고 풍부한 쇼핑정보를 제공하고 의사결정에 도움이 될 수 있는 상품에 대한 재구매 정보를 빠르게 제공하는 등 쇼핑정보 획득이 용이하여 나타났 다고 할 수 있다. 이 결과는 스마트폰 쇼핑몰의 정보제공 품질 이 고객만족에 정(+)의 영향을 준다는 기존연구와 일치한다 (Kim, 2017; Cho et al., 2016; Choi, 2012a).

셋째, 스마트폰 쇼핑몰을 이용하는 소비자의 고객만족이 행 동의도에 정(+)의 영향을 주는 것으로 나타났다. 고객만족이 높을수록 행동의도가 더 높은 것으로 나타났다. 이것은 스마트 폰 쇼핑몰을 이용하는 고객들이 이전에 접속하였던 쇼핑몰을 우선 선택할 정도로 다시 이용할 예정으로 설명할 수 있다. 또 한 구매의사가 없어도 다시 접속하는 등 계속 이용할 것이며 주변 친지들이 추천을 원하는 경우 우선 적극적인 추천을 할 수 있는 것으로 설명할 수 있다. 이 결과는 스마트폰 쇼핑몰의 높은 서비스품질에 의해 영향을 받은 고객만족이 행동의도에 정(+)의 영향을 미친다는 기존연구와 일치한다(Kim \& Jeon, 2016; Jung \& Kim, 2014).

넷째, 편리성 품질, 고객서비스 품질, 그리고 상품 품질 등 은 고객만족에 각각 정(+)의 영향을 주지 않는 것으로 나타났 
다. 이것은 스마트폰 쇼핑몰 이용자들이 사용하기 쉬운 메뉴나 알기 쉬운 화면 구성, 사이트나 상품파악의 용이성, 다양한 상 표나 상품구성, 화면 분위기 등보다 용이한 접속환경 및 빠른 응답속도, 웹사이트의 구성배치 및 그래픽, 객관성 있고 신속 하며 풍부한 쇼핑 정보 품질을 더 중요시 하여 나타난 현상으 로 설명할 수 있다. 이 결과는 스마트폰 쇼핑몰의 서비스품질 이 고객만족에 영향을 미친다는 기존연구와 일치하지 않고 있 다(Cho et al., 2016; Wang \& Yum, 2015; Choi, 2012a).

다섯째, 스마트폰 쇼핑몰 이용자들은 정보제공 품질, 시스템 품질, 웹디자인 품질 등의 순으로 고객만족에 영향을 주는 것 으로 나타났다. 따라서 스마트폰 쇼핑몰 이용자들은 스마트폰 쇼핑몰의 용이한 접속환경 및 빠른 응답속도, 웹사이트의 구성 배치 및 그래픽 등보다 스마트폰 쇼핑몰의 객관성 있고 신속 하며 풍부한 쇼핑 정보 품질을 더 중요하게 평가하는 것으로 분석되었다. 이것은 스마트폰 쇼핑몰의 이용자들이 자신의 욕 구에 맞는 상품에 대한 풍부한 정보를 내 손안의 스마트폰을 통해 쉽고 신속하게 획득하기를 원한다는 기존연구와 일치한 다(Cho et al., 2016; Choi, 2012a).

마지막으로, 스마트폰 쇼핑몰의 서비스품질에 대한 신뢰가 고객만족과 행동의도와의 관계에서 어떤 영향을 주는가를 실 증하기 위해 조절회귀분석을 실시하였으며, 그 결과는 고객만 족과 행동의도와의 사이에서 신뢰는 조절효과를 갖지 못하는 것으로 나타났다. 이것은 인터넷 쇼핑몰에서 신뢰가 고객만족 과 행동의도와의 관계에서 신뢰는 조절효과를 갖지 못한다는 기존연구와는 일치한다(Yang \& Shim, 2017).

한편 본 연구는 앞에서 언급한 연구결과들을 기반으로 할 때 학술적 시사점과 실무적 시사점을 가질 수 있는데, 그것은 다음과 같다. 먼저, 학술적 의미는 스마트폰 쇼핑몰의 서비스 품질들을 시스템 품질, 웹디자인 품질, 편의성 품질, 정보제공 품질, 고객서비스 품질, 상품 품질 등으로 확대하여 분류할 수 있었다는 점이다. 이 서비스품질들을 선행변수로 스마트폰 쇼 핑몰의 서비스품질 $\rightarrow$ 고객만족 $\rightarrow$ 행동의도의 경로구조로 실증 적으로 검증하였다는 것이다. 스마트폰 쇼핑몰의 기존연구에서 서비스품질은 Parasuraman et al.(1988)과 Parasuraman et al. (2005)의 SERVQUAL와 e-SERVQUAL을 분류하여 사용하였다 (Cho et al., 2016; Choi, 2012b). 본 연구는 스마트폰 쇼핑몰 및 온라인 산업의 서비스품질, Lee의 e-SERVQUAL(2002)과 Parasuraman et al.(1988)과 Parasuraman et al.(2005)의 SERVQUAL과 e-SERVQUAL 등을 바탕으로 스마트폰 쇼핑몰 의 서비스품질을 분류하고 분류된 유무형의 서비스품질인 선 행변수들과 결과변수와의 영향관계를 실증한 것이다. 둘째, 실 무적 의미는 스마트폰 쇼핑몰의 거래에서 소비자들이 요구하 는 다양한 서비스품질에 맞는 물리적 환경 개선 및 서비스 개 발이 필요하다는 것을 스마트폰 쇼핑몰의 마케터에게 제안할 수 있다는 것이다. 스마트폰 쇼핑몰 이용자들은 스마트폰 쇼핑 몰의 용이한 접속환경 및 빠른 응답속도, 웹사이트의 구성배치 및 그래픽 등보다 스마트폰 쇼핑몰의 객관성 있고 신속하며 풍부한 쇼핑정보 품질을 더 중요하게 평가하고 있기 때문에 스마트폰 쇼핑몰의 마케터들은 정보제공 품질과 시스템 품질 들을 더 검토할 필요가 있다.

\section{2. 연구의 한계 및 향후 연구방향}

본 연구는 기존연구에서 사용되고 있는 스마트폰 쇼핑몰의 서비스품질과 서비스산업의 서비스품질 등을 바탕으로 스마트
폰 쇼핑몰의 서비스품질과 고객만족과의 관계, 고객만족과 행 동의도와의 관계를 검증하였다. 본 연구의 수행에서 나타나고 있는 한계점과 향후 연구방향은 아래와 같다. 먼저, 본 연구에 나타난 결과에서 고객서비스 품질이 지지되지 못하여 많은 기 존연구의 결과와 비교할 때 의외의 결과라 할 수 있다. 따라서 향후 연구에서는 스마트폰 쇼핑몰에서 서비스의 비중이 높지 않은 것인지 비교분석할 필요가 있다. 둘째, 본 연구는 스마트 폰 쇼핑몰의 선행변수와 결과변수에 대한 요인분석에서 두 변 수들을 동시에 요인분석을 할 경우 몇 개의 요인에서 다수의 측정항목들을 제거해야만 하였다. 따라서 향후의 연구는 이 부 분에 대한 정확한 분석을 통해 이 요인의 적절한 분류를 확인 해야 할 필요가 있다.

\section{References}

Ahn, K. H., \& Lee, Y. J. (2002). The Study of Customer Shopping Orientation on the Relationship between Store Image Variables and On-line Consumer's Purchase Intention. Journal of Consumer Studies, 13(4), 101-122.

Chaiy, S. I. (1999). Social Research Method and Analysis (Second Edition). Seoul, Korea: Hakhyunsa Publishing.

Chang, K. R., \& Kim, M. C.(2012). Relationship Between Application Service Quality of Professional Sport Teams and Elements of Team Value. Korean Journal of Sport Management, 17(5), 13-30.

Cho, C. H. (2009, November). The Effect of Web Service Quality on User Satisfaction and Loyalty Intent: Moderating Effect of Trust and Commitment in Small and Medium Size Hospital Homepage. Proceedings of DAEHAN Association of Business Administration, 541-567.

Cho, C. H., \& Kang B. S. (2009). An Effect of Website Quality on Customer Satisfaction and Loyalty Intention: Moderating Effect of Trust and Flow in Internet Banking. The Academy of Customer Satisfaction Management, 11(1), 57-74.

Cho, C. H., \& Shine, E. K. (2009). An Effect of Service Quality on Customer Satisfaction and Re-use Intent: Focusing on Moderating Effect of Trust in Large-size Hospitals. Health Service Management Review, 3(1), 79-88.

Cho, I. H., Song, J. G., \& Jeon, M. H. (2016). A Study on Effect of Repurchase Intention and Customer Satisfaction of E-Service Quality with Application of Smart Phone(Focused on Franchise of Coffee). Journal of the Korean Industry Association, 10(5), 277-286.

Choi, H., \& Choi, Y. J. (2011). The Impact of Smartphone Application Quality Factors on Trust and the User's Continuance Intention According to Gender. Journal of the Korean Industry Information, 16(4), 151-162.

Choi, H. K., Park, J. M., \& Lee, D. Y. (2008). A Study on the Influence of Customer Values on the Purchase Intention in Internet Shopping Mall. Journal of Business 
Education Research, 17, 423-445.

Choi, J. A. (2012a). A Study on the Factors of Travel Application Service Quality a Effects Customer Satisfaction and Intention of Reuse. Master Dissertation, Sejong University.

Choi, Y. R. (2012b). A Study on Factors of Service Quality in Food Service Industry Smartphone Applications and Their Effects on Customer Satisfaction and Return Intention. Master Dissertation, Kyonggi University.

Cronin, Jr. J. J., \& Taylor, S. A. (1992). Measuring Service Quality: A Reexamination and Extension. Journal of Marketing, 56(July 1992), 55-68.

Edward, M., \& Sahadev, S. (2011). Role of Switching Costs in the Service Quality, Perceived Service Value, Customer Satisfaction and Customer Retention Linkage. Asia Pacific Journal of Marketing and Logistics, 23(3), 327-345.

Feigenbaum, A. V. (1991). Total Quality Contro/(3rd Ed.). New York, NY: McGraw-Hill.

Jang, H. Y. (2007). A Comparative Study on the Structural Interactions Among Customer Satisfaction, Trust, Loyalty Based on Types of Internet Shopping Mall. Journal of Korean Academy of Marketing Science, 17(1), 23-49.

Jang, Y. H., Park M. H., \& Kim, S. W. (2005). The Influence of Consumers' Store Choice Decision Criteria on Patronage Intention and Perceived Value in Internet Shopping. Journal of Business Research(Korean), 20(1), 29-55.

Jeun, S. T., \& Lee, H. J. (2012). The Effect of Service Quality on the Customer Satisfaction and the Customer Loyalty in Internet Shopping Mall. Journal of KECRA, 13(1), 59-85.

Jung, D. Y., \& Kim, S. Y. (2014). The Effects of the Service Quality of Smartphone Applications of Airline on Customer Satisfaction and Behavior Intention. Proceedings of Korean Association of Business Administration, 3543-3556.

Jung, W. J., \& Lee, K. K. (2013). The Effects of the Service Quality of Smartphone Applications on User Satisfaction and Loyalty. Society of Korea Industrial and systems Engineering, 36(3), 79-86.

Kim, E. H. (2012). Research on Practical Shopping Value and Consumer Attitudes on PB Products According to Perceived Quality. Journal of Distribution Science, 10(10), 35-43.

Kim, H. J., Leem, J. U., \& Jang, J. H. (2011). A Study on the Impact of Customer Satisfaction and Repurchase Intention by the Characteristics of the Airline's Smartphones Application According to Customer Types. Journal of Europe and Russia Research, 8(3), 47-69.

Kim, M. J. (2017), The Impact of APP Quality on Customer Satisfaction of Smartphone Offering 020 Service in the Food Service Industry: Focusted on the
Technology Acceptance Model. Master Dissertation, Hanyang University.

Kim, M. J., \& Jeon H. M. (2016). Influence of Smart Phone 'Majib Apps' Service Quality Based on Bog Data on Perceived Usefulness, Use Satisfaction, and Behavior Intention. Journal of Hotel and Tourism, 18(2), 198-219.

Kim, H. K., \& Cho, H. J. (2013). The Effects of Consumption Value of Smartphone Users on Relational Factors and Repurchase Intention. Journal of Distribution Science, 11(4), 73-80.

Kim, H. S., \& Shim, J. H. (2017). The Effects of Service Qualities on Customer Satisfaction and Behavioral Intention in Coffee Shops. International Journal of Industrial Distribution \& Business, 10(10), 35-43.

Kwon, S. H., Kim, T. U., \& Lee, Y. K. (2003). The Roles of Consumer's Perceived Value, Satisfaction, Trust and their Relationship with Loyalty in Internet Shopping Environment. Korean Management Science Review, 20(1), 149-164.

Lee, J. B., \& Baek, D. H. (2017). A Study on Influence of Smartphone Business Factors on Customer Satisfaction and Customer Loyalty. The Journal of Society for e-Business Studies, 22(2), 19-38.

Lee, G. G., \& Lin, H. F. (2005). Customer Perceptions of e-service Quality in Online Shopping. International Journal of Retail \& Distribution Management, 33(2), 161-176.

Lee, J. C. (2012). Analysis on the Mediator of Ease of Use, Usefulness and Switching Barrier on Customer Satisfaction in Context of Service Quality of Smartphone. Journal of Business Research, 27(4), 175-198.

Lee, M. K. (1999). A Study on the Determinants of Service Loyalty. Korean Marketing Review, 14(1), 21-45.

Lee, M. K. (2002). e-SERVQUAL: A Scale for Measuring Customer Evaluation of Internet Service Quality. Korean Marketing Review, 17(1), 73-95.

Lim, C. K. (2005). A Study on the Relationship of Service Quality, Customer Satisfaction and Repurchasing Intention in the Internet Shopping Malls. Economics and Business Research of Kyungsung University, 21(1), 69-82.

Li, C. J., Lee, H. J., \& Jeun, S. T. (2013). A Study on Internet Shopping Mall Customer Perceived Service Quality, Customer Satisfaction, and Repurchase Intentions(Emphasis on Moderating Effect of Shopping Interest). Journal of KECRA, 14(1), 3-28.

Park, J. H., \& Lee, S. H. (2013). A Study on the Quality Determination Factors of the Consulting Service Affecting the Customer Satisfaction and the Repurchase Intent: Focused on the 'Consulting Service of PatentR\&D Link Strategy. Korean Management Consulting Review, 13(1), 25-54.

Parasuraman, A., Zeithaml, V. A., \& Berry, L. L. (1985). A Conceptual Model of Service Quality and Its Implications 
for Future Research. Journal of Marketing, 49(Fall), 41-50.

Parasuraman, A., Zeithaml, V. A., \& Berry, L. L. (1988). SERVQUAL: A Multiple-Item Scale for Measuring Consumer Perceptions of Service Quality. Journal of Retailing, 64(1), 12-40.

Parasuraman, A., Zeithaml, V. A., \& Berry, L. L. (1991). Refinement and Reassessment of the SERVQUAL Scale. Journal of Retailing, 674), 420-450.

Parasuraman, A., Zeithaml, V. A., \& Malhotra A. (2005). E-S-QUAL a Multiple-item Scale for Assessing Electronic Service Quality. Journal of Service Research, 73), 213-233.

Prabha R. M. (2012). Perceived service Quality in Restaurant Services: Evidence from Mauritius. International Journal of Management and Marketing Research, 5(3), 1-14.

Qin, H., \& Prybutok, V. R. (2008). Determinants of Customer-Perceived Service Quality in Fast-food Restaurants and Their Relationship to Customer Satisfaction and Behavioral Intentions. The Quality Management Journal, 15(2), 35-50.

Raza, M. A., Siddiquei, A. N., Awan, H. M., \& Bukhari, B. Z. (2012). Relationship Between Service Quality, Perceived Value, Satisfaction and Revisit Intention in Hotel Industry. Interdisciplinary Journal of Contemporary Research in Business, 4(8), 788-805.

Shang, Y. F., Chen. Y., \& Kim, H. S. (2017). Effect of
Experiential Value on Customer Satisfaction and e-WOM under O2O Commerce. Journal of Distribution Science, 15(8), 75-86.

Shen, L. (2014). A Study on the Market Prospect of Smart Phone and the Consumer Satisfaction Repurchase Intention of Chinese Overseas Student Smart Phone User in Korea. Journal of Korean Academic Society of e-Business, 5(1), 27-46.

Tsou, C. W., \& Liao. C. H. (2010). Investigating the Antecedents of Customer Loyalty to Broadband Network Services in Taiwan. Asia Pacific Management Review, 15(3), 413-433.

Wang, W., \& Yum, C. S. (2015). The Effect of Service Quality on Customer Satisfaction of Smart Phone Banking. Journal of KIIT, 13(4), 95-102.

Yang, S. K., \& Shim, J. H. (2017). The Effects of Quality Factors on Customer Satisfaction and Behavior Intention in Internet Shopping Malls: Focusing on College Students. Journal of Distribution and Management research, 20(1), 65-79.

Yoon, D. K. (2012). Factors Affecting in Online Shopping and the Relationship between Belief and Purchase Intention: Product Pattern(voluptuous product/utilitarian product). Journal of e-Business Studies, 13(5), 227-249.

Yi, Y. J. (2005). Service Marketing(3rd Ed.). Paju, Korea: Hakhyunsa. 